\title{
CHILD LABOR AND SCHOOLING RESPONSES TO ACCESS TO MICROCREDIT IN RURAL BANGLADESH
}

\author{
ASADUL ISLAM and CHONGWOO CHOE*
}

\begin{abstract}
Microcredit has been shown to be effective in reducing poverty in many developing countries. However, less is known about its effect on human capital formation. In this article, we examine the impact of access to microcredit on children's education and child labor using a new and large data set from rural Bangladesh. The results show that household participation in a microcredit program may increase child labor and reduce school enrollment. The adverse effects are more pronounced for girls than boys. Younger children are more adversely affected than their older siblings and the children of poorer and less educated households are affected most adversely. Our findings remain robust to different specifications and methods, and when corrected for various sources of selection bias. (JEL H43, I21, J13, J24, L30, O12)
\end{abstract}

\section{INTRODUCTION}

Microcredit programs have expanded rapidly in recent decades in the developing world. They have reached more than 20 million borrowers in Bangladesh, about $60 \%$ of the country's poor rural households (World Bank 2006). The United Nations declared 2005 as the International Year of Microcredit, and urged multilateral donor agencies and developed countries to support the microfinance movement to achieve its Millennium Development Goal of halving poverty by 2015 . The success and popularity of microcredit over the past decades are evidenced by the fact that there are more than 7,000 microfinance institutions (MFIs) today, serving millions of poor people, and that microcredit

*We are thankful to Dietrich Fausten, Ronald Caldwell, John Gibson, Guang-Zhen Sun, Michael Keane, Glenn Harrison, Bruce Weinberg, Mark Harris, Pushkar Maitra, Chikako Yamauchi, Gigi Foster, Frank Vella, participants at the Western Economic Association annual conference in Vancouver, Managing Selection Workshop at the University of South Australia, the fourth Australasian Development Workshop at the Australian National University, two anonymous referees of this journal, and seminar participants at Monash University and Bangladesh Institute of Development Studies (BIDS) for very helpful comments and suggestions. The usual disclaimer applies.

Islam: Lecturer (Assistant Professor), Department of Economics, Monash University, Caulfield East, VIC 3145, Australia. Phone +61 39903 2783, Fax +61 39903 1128, E-mail Asadul.Islam@monash.edu

Choe: Professor, Department of Economics, Monash University, Caulfield East, VIC 3145, Australia. Phone +61 39903 4520, Fax +61 39903 1128, E-mail Chongwoo.Choe@monash.edu has proved to be an important instrument in helping "large population groups find ways in which to break out of poverty" (The Norwegian Nobel Committee's press release in awarding the Nobel Peace Prize for 2006 to Grameen Bank and its founder Muhammad Yunus).

If access to microcredit helps reduce poverty, then one might surmise that it could also improve investment in children's education. This is because underdeveloped credit markets coupled with low household income (Baland and Robinson 2000; Doepke and Zilibotti 2005; Ranjan 1999) or lack of access to credit are often considered major factors responsible for inadequate education for children in developing countries (Dehejia and Gatti 2005; Edmonds 2006, 2007; Jacoby and Skoufias 1997; Ranjan 2001). Access to credit can have a positive effect on children's education through a number of channels. First, to the extent that credit may increase the borrower's income, the income effect may positively affect the demand for children's schooling (Behrman and Knowles

\[ \text { ABBREVIATIONS } \]
i.i.d.: Independent and Identically Distributed
IV: Instrumental Variable
LPM: Linear Probability Model
MFI: Microfinance Institutions
MO: Microcredit Organization
PKSF: Palli Karma-Sahayak Foundation
2SLS: Two-Stage Least Squares

\section{ABBREVIATIONS}

ent and Identically Distributed

IV: Instrumental Variable

LPM: Linear Probability Model

MFI: Microfinance Institutions

PKSF: Palli Karma-Sahayak Foundation

2SLS: Two-Stage Least Squares 
1999). Second, the vulnerability of rural households to adverse exogenous shocks may force them to pull their children out of school in times of need, hampering sustained school enrollment for their children. Loans from microcredit organizations (MOs) can assist consumption smoothing, thereby reducing the likelihood that children are withdrawn from school in response to adverse shocks. Third, preferences toward schooling may also be influenced by mandatory adult training programs conducted by MOs. Although MOs in general do not have any direct declared objective of improving children's education, they do educate members about the potential benefits of sending children to school. For example, Grameen Bank members need to memorize 16 decisions, one of which is, "we shall educate our children."

On the other hand, microcredit may also have unintended consequences on children's education for several reasons. First, microcredit loans often require establishment of household enterprise that requires extra labor to work in it. For example, if a household uses microcredit loans to purchase livestock, it will require labor to take care of the animals, which can increase the demand for child labor. Second, the amount of loan is not large enough to hire external labor, which may compel the household to resort to child labor. ${ }^{1}$ Third, the loan repayment period is short and interest rate is high, making the household myopic, which may induce parents to heavily discount the future return on their children's education. ${ }^{2}$ To service the loan, it may be necessary to supplement household income, at least temporarily, with the proceeds from child labor. Therefore, the additional activities made possible by access to microcredit and the factors related to servicing the terms of microcredit loan may adversely affect children's education. ${ }^{3}$ Children may need to be employed directly in

1. Loan size varies but is typically between US\$40 and US $\$ 150$. However, members may take larger loans after repaying their first loan. Loans are made for any profitable and socially acceptable income generating activities such as poultry, livestock, sericulture, fisheries, rural trading, rural transport, paddy husking, food processing, small shops, and restaurants.

2. Typical interest rates on microcredit loan are above $30 \%$ on a reducing-balance basis and most MOs require that households start repaying the loans 4 weeks after obtaining credit. The effective interest rates are even higher because of commissions and fees charged by MOs. The frequency of repayments and the systems adopted to collect repayments also raise the effective interest rates.

3. In an earlier version of this article (Islam and Choe 2009), we provide a theoretical model showing that access to microcredit can result in increased child labor if the credit the newly created or expanded household enterprises, or as caregiver for their siblings, or in farm and livestock duties, and other household chores.

There is conflicting evidence on the impact of microcredit on human capital formation. One strand of empirical studies suggests that access to credit can help reduce child labor and increase schooling in developing countries. For example, Jacoby (1994) finds that unequal access to credit is an important source of inequality in schooling investment in Peru. Dehejia and Gatti (2005) find a negative association between child labor and access to credit across various countries. Jacoby and Skoufias (1997) observe that, in India, the incidence of child labor increases as access to credit becomes more difficult. ${ }^{4}$ The second strand of literature finds ambiguous results. Wydick (1999) reports that the relation between access to microcredit and children's schooling is not unambiguously positive in the case of Guatemala. He finds that a child is more likely to work in a household enterprise when the household borrowing is used for capital equipment instead of working capital. A similar conclusion is drawn by Maldonado and Gonzalez-Vega (2008), who find that households demand more child labor if they cultivate land and operate labor-intensive microenterprises. On the basis of microcredit programs in Bangladesh, Pitt and Khandker (1998) find that girls' schooling is positively affected when women borrow from Grameen but not so when they borrow from other microcredit programs. Banerjee et al. (2009) find that treated microcredit households are not more likely to have children in school, and they do not spend more on tuition, school fees, and uniforms. Hazarika and Sarangi (2008) report that, in rural Malawi, children tend to work more in households that have access to microcredit. On the other hand, Karlan and Zinman (2009) find that male microentrepreneurial borrowers in Manila use loan proceeds to send their children to school.

Given the limited and conflicting evidence summarized above, the purpose of this article is to examine the impact of household participation in microcredit programs on both children's schooling and child labor using a new,

cannot be used to hire external labor and the required returns on investment are high. As indicated in footnotes 1 and 2 above, both conditions are likely to hold for microcredit programs in Bangladesh that we study.

4. Similar results are reported in Beglee, Dehejia, and Gatti (2005) for Tanzania and Edmonds (2006) for South Africa. 
large, nationally representative data set based on a survey conducted in Bangladesh in 1998. Our empirical findings contribute to the literature in three ways. First, our results show that participation in microcredit programs adversely affects children's schooling and exacerbates the problem of child labor. The results overwhelmingly indicate that girls are more likely to be affected adversely, although the effect on boys is ambiguous. It is also shown that younger children, who are more exposed to the program, are more likely to be put to work and less likely to attend school as their parents take out microcredit. Second, we show how the adverse effect differs depending on the gender of participating parents. Although the adverse effect does not differ much whether credit is obtained by women or men, we find some evidence for gender preferences: the adverse effect on girls' schooling tends to be smaller when credit is obtained by mother than when it is obtained by father. Finally, we examine the possible channel through which microcredit adversely affects children's education. Our results show that, for children from participating households, the odds of being in self-employment activities instead of being in school are more than doubled than nonparticipating households. This suggests that increased child labor is in large part because of household enterprises set up with microcredit. Our empirical findings remain robust to different specifications and methods, and when corrected for various sources of selection bias.

Overall, our results suggest that care needs to be taken in assessing the effectiveness of microcredit programs. On one hand, successful microcredit programs can alleviate poverty and contribute to rural economy. On the other hand, they can alter parents' incentives in a way that adversely affects children's schooling, which could exacerbate poverty in the longer term. ${ }^{5}$ In

5. One may ask if the negative effect on children's education is necessarily bad if children can make up for lower education by working in family enterprises, which may increase their future earnings. To answer the question, we need information on returns to education and returns to working in family enterprises. Unfortunately, this is beyond the scope of this study because we only look at the contemporaneous effect of microcredit. A panel data set over a longer term participation in microcredit may help us understand the issue better. On the other hand, the longterm effect of microcredit on children's education could be different from what we find in this study: the higher income opportunities provided by microcredit over time could lead to an income effect toward less child labor and more education that may outweigh the substitution effect. We leave this and related questions for future study when more information becomes available. addition, the adverse effect that falls unequally on girls would reduce the effectiveness of policies to promote gender equality in education in developing countries. In summary, microcredit programs need to be complemented by other policies to tackle the multiple goals of poverty reduction, human capital formation, and social development.

The rest of this article is organized as follows. Section II describes our data and presents descriptive statistics. Section III discusses issues related to our empirical methodology and Section IV reports the main empirical findings. Section V concludes this article.

\section{THE PROGRAM, DATA, AND DESCRIPTIVE STATISTICS}

\section{A. The Program and Data}

The data were collected by the Bangladesh Institute of Development Studies on behalf of the Palli Karma-Sahayak Foundation (PKSF; Rural Employment Support Foundation) with support from the World Bank. ${ }^{6}$ This survey is the largest and the most comprehensive of the microcredit programs that operated in Bangladesh at that time period. Its geographic coverage is spread evenly across Bangladesh, and the sub-district (thana) level comparisons reveal that selected sub-districts are not different from the average (Zohir et al. 2001). The data cover 13 MOs of different sizes in terms of operations and membership. These MOs were selected to constitute a nationally representative data set for the entire microcredit program in Bangladesh. The most notable MOs studied in this article are ASA and Proshikha, the third and fourth largest MOs, respectively, in Bangladesh. All 13 MOs follow the Grameen Bank-style lending procedure and typically give access to microcredit to households owning less than a half-acre of land.

The survey includes 13 districts covering 91 villages spread over 23 sub-districts in Bangladesh. A census of all households in the 91 villages was conducted before the survey was administered in early 1998. There were 80 treatment villages and 11 control villages (villages without microcredit program during the survey). The actual targeting of survey households involves two stages: (a) the selection of

6. The PKSF is the apex organization for microfinance. The microlending community regards it as a regulatory agency and it exercises authority over the MOs. 
the villages where MOs operate and (b) the selection of households within the selected villages. In the absence of adequate control households, some selected nonparticipants from the program villages who are observationally similar and expressed willingness to participate in microcredit program were also surveyed as the control group. Participation in a credit program was defined in terms of current membership reported during the census. From the village census lists of households, 34 households were drawn from each program and nonprogram village. The selections of villages and household sample are described in detail by Zohir et al. (2001).

\section{B. Descriptive Statistics}

The original survey consists of 3,026 households. In this article, we consider the subset of 2,034 households who have at least one child aged 7-16 at the time of the survey. This represents a total of 4,277 children of which 2,658 belong to treatment households and the remainder to the control group. Our sample contains both male and female borrowers but the former accounts for only $12 \%$ of all borrowers (and 133 households) representing 281 children. Among all children, $54.2 \%$ are boys.

The household-level questionnaire includes primary and secondary activity of each child. We define "child laborer" as anyone aged 7-16 who performs any economic activity (i.e., if a parent answers "employed," "household work," or "employed but not working"). A child is considered to be in school if he/she is currently enrolled in school and attended school in the last month of the survey period. By this definition, $77.4 \%$ of girls aged $7-16$ in the sample were classified as being in school and $10.4 \%$ in work. The corresponding figures for boys are $71.3 \%$ and $15.7 \%$, respectively. Other children are reported to be neither working nor in school, and possibly many of them are helping parents with household work. So there may well be under-reporting of child labor. The results by participation status are reported in Table 1. School enrollment is lower and

TABLE 1

Descriptive Statistics of Child and Household Characteristics

\begin{tabular}{|c|c|c|c|}
\hline Variables & Treatment $(I)$ & Control (II) & Difference $\mathbf{I I I}=(\mathbf{I}-\mathbf{I I})$ \\
\hline \multicolumn{4}{|l|}{ Child characteristics $(7-16$ years old) } \\
\hline \multicolumn{4}{|l|}{ Child in work $(\%)$} \\
\hline Boys & 16.9 & 13.8 & 3.0 \\
\hline Girls & 11.0 & 9.3 & 1.7 \\
\hline \multicolumn{4}{|l|}{ Child in school $(\%)$} \\
\hline Boys & 69.3 & 74.7 & $-\mathbf{5 . 5}$ \\
\hline Girls & 76.6 & 78.9 & -2.3 \\
\hline Age of child (years) & 11.497 & 11.494 & 0.003 \\
\hline Sex of child (percentage of girls) & 55.7 & 55.6 & 0.1 \\
\hline \multicolumn{4}{|l|}{ Household characteristics } \\
\hline Mother age (years) & 37.66 & 38.14 & -0.48 \\
\hline Mother schooling (years of education) & 1.09 & 1.54 & -0.45 \\
\hline Father age (years) & 45.85 & 46.80 & -0.95 \\
\hline Sex of household head $($ male $=1)$ & 0.93 & 0.95 & 0.026 \\
\hline Father schooling (years of education) & 2.64 & 3.20 & -0.56 \\
\hline Household size & 6.56 & 6.48 & -0.08 \\
\hline \multicolumn{4}{|l|}{ Number of children } \\
\hline $0-6$ years & 0.81 & 0.79 & 0.02 \\
\hline $6-16$ years & 2.79 & 2.66 & 0.13 \\
\hline \multicolumn{4}{|c|}{ Maximum education by any household member } \\
\hline Male borrower (years of education) & 4.78 & 5.29 & -0.50 \\
\hline Female borrower (years of education) & 4.17 & 4.57 & -0.40 \\
\hline Amount of land (decimals) & 64.7 & 91.2 & -26.6 \\
\hline Number of children observations & 2,568 & 1,709 & - \\
\hline Number of households in the sample & 1,241 & 793 & - \\
\hline
\end{tabular}

Notes: The last column presents the difference between columns (I) and (II). Differences that are statistically significant at less than $5 \%$ are marked bold. 


\section{FIGURE 1}

Proportion of Children in School

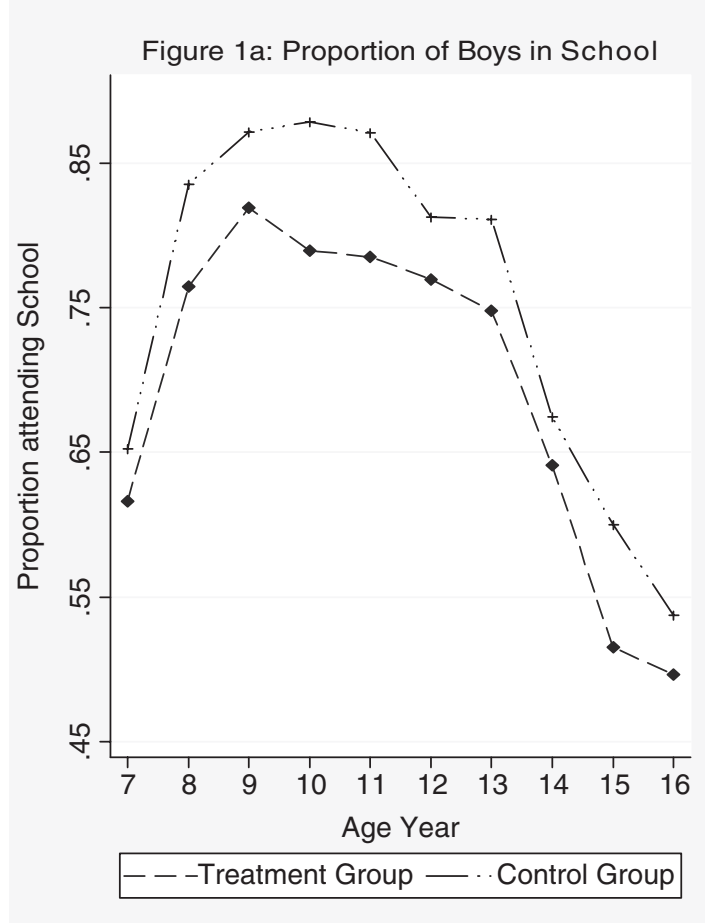

Figure 1b: Proportion of Girls in School

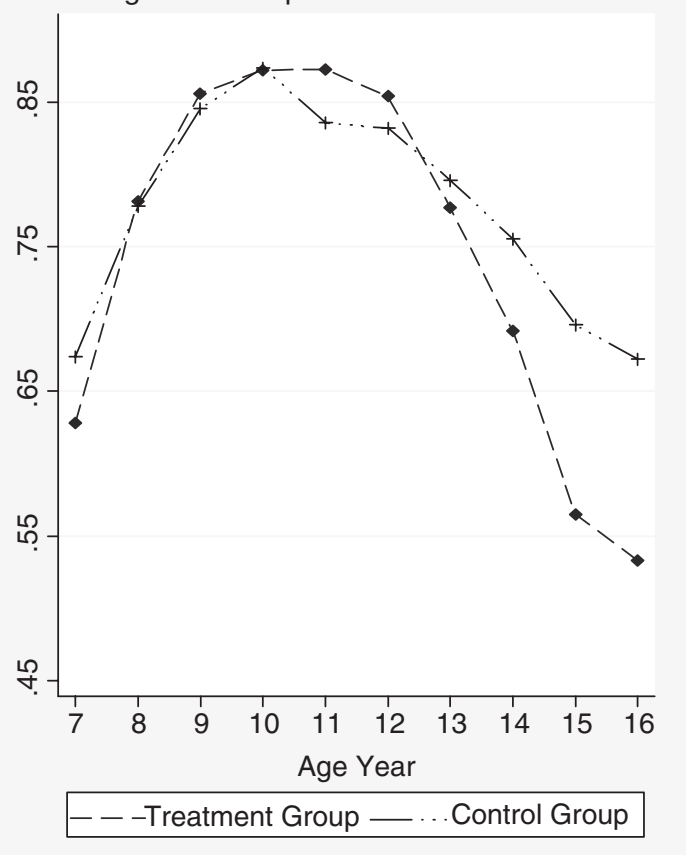

child labor higher among children of the treatment group. We find a statistically significant difference in school enrollment and child labor between boys of treated and untreated households, but no such difference exists for girls. However, the difference in school enrollment between girls and boys is larger in the treatment group.

Figure 1 plots school enrollment of children by age for both sex groups. Children at high school age (12-16 years old) are less likely to be enrolled in school because of dropouts. At primary school age, the proportion of children aged 7-8 enrolled in school is lower than their older counterpart (9-11 years old), indicating that there are a considerable number of children who start schooling at a later age. The difference between treatment and control groups in school enrollment is larger for boys. Girls aged 7-11 have a similar rate of enrollment in both treatment and control groups, but after age 13, girls in the control group tend to have a lower enrollment rate. On average, children

at primary school age have a higher enrollment rate compared with their older siblings, the latter more likely to drop out from school and go to work. Overall, a higher proportion of children from treated households is in work (Figure 2).

Table 1 also provides other descriptive statistics for child and household characteristics. It shows that the average age of children is 11.5 years for both groups of households. There is no difference between treatment and control groups in the gender composition of children. The treatment group has slightly more members in the household than the control group. For each household, the average number of children under the age of 18 is four. Nontreated households tend to be better educated, a little older but smaller in household size.

\section{EMPIRICAL METHODOLOGY}

In estimating the impact of microcredit on children's school enrollment and child labor, we follow a standard methodology (Edmonds 


\section{FIGURE 2}

Proportion of Children in Work

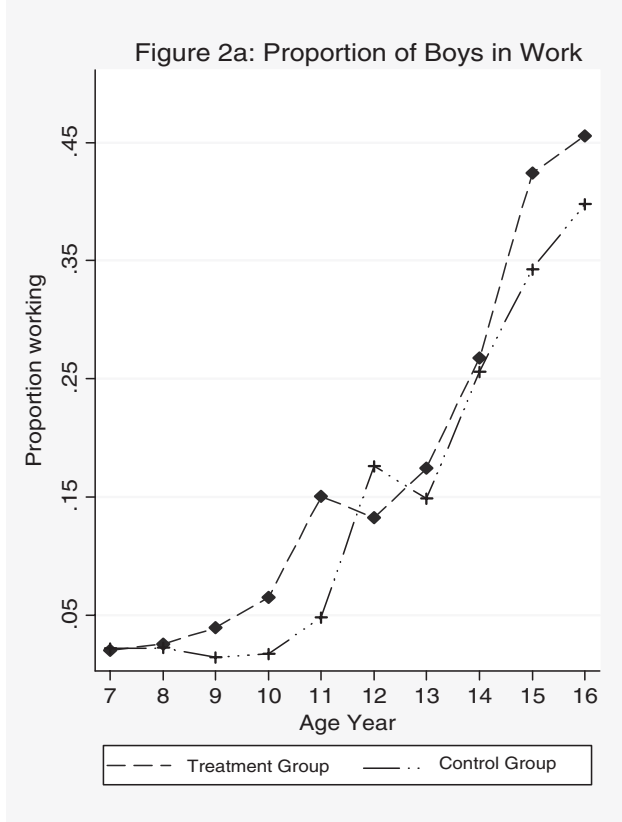

Figure 2b: Proportion of Girls in Work

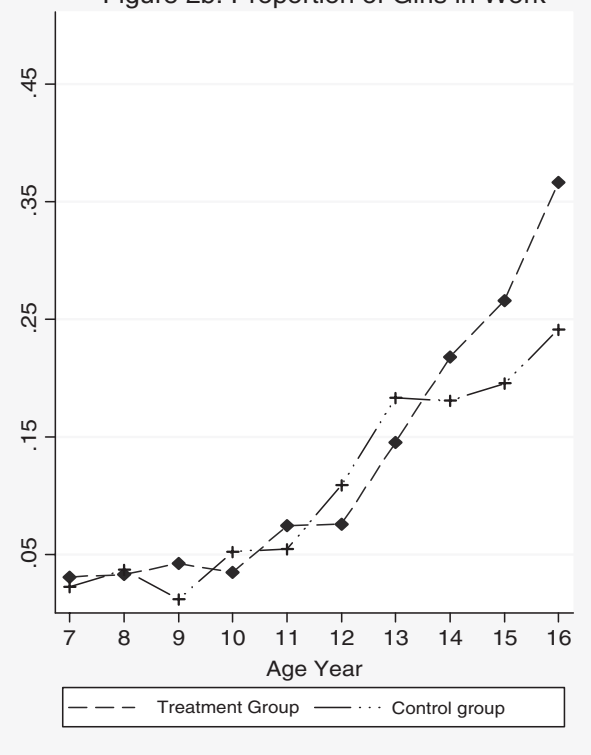

2006; Ravallion and Wodon 2000; Wydick 1999). Let $S_{i}$ be a binary variable that denotes whether child $i$ attends school $\left(S_{i}=1\right)$ or not $\left(S_{i}=0\right){ }^{7}$ We estimate the impact of participation in microcredit programs on children's schooling with the following equation:

(1)

$$
S_{i j k l}=\beta_{0 l}+\beta_{1} X_{i j k l}+\beta_{2} \text { Credit }_{j k l}+\beta_{3} Z_{k}+\varepsilon_{i j k l}
$$

where the subscripts index child $(i)$, household $(j)$, village $(k)$, and district $(l)$. $\boldsymbol{X}$ is a vector of child- and household-specific covariates and $\boldsymbol{Z}$ is a vector of village-specific covariates. $\beta_{0 l}$ captures fixed effects. Credit is a continuous treatment variable defined by the amount of microcredit borrowed by the household. It is equal to 0 if a household did not participate in a microcredit program. $\boldsymbol{Z}_{k}$ incorporates either village-level fixed effects or village-level

7. A child may be reported to be both in school and in work, perhaps helping parents in household work while attending school. In our sample, only $1 \%$ of children belong in this category, so we ignore this case from our regression. It is usual in rural areas of Bangladesh that parents arrange a modest amount of part-time work for their children while still keeping them at school. See, for example, Ravallion and Wodon (2000).

control. The error term $\varepsilon_{i j k l}$ is assumed to be independent and identically distributed (i.i.d.). The variables in $\boldsymbol{X}$ include the age of child, the age of child squared, dummies for birth order, the age of household head, education and sex, the level of highest education of any member in the household, presence of father, presence of mother in the family, mother's schooling, and the amount of arable land. Our results did not change when we included a larger set of controls. The village-level covariates in $\boldsymbol{Z}$ include, among others, separate dummies for the presence of primary school, secondary school or college, religious school, health facility, post office, brick-built road, grocery market, bus stand, distance to nearest sub-district, adult male wage, and price of rice. The descriptive statistics for the full list of village-level covariates are provided in Table A1. As shown in the table, the differences in village-level covariates are mostly insignificant, indicating that these differences are not the main driving force for our results.

For the effect of microcredit on child labor, our estimating equation is as follows:

$$
\begin{aligned}
W_{i j k l}= & \alpha_{0 l}+\alpha_{1} X_{i j k l}+\alpha_{2} \text { Credit }_{j k l} \\
& +\alpha_{3} Z_{k}+v_{i j k l}
\end{aligned}
$$


where $W$ is a binary variable that is equal to 1 if child works and 0 otherwise. All other variables are as explained above, $v$ is the error term representing omitted characteristics and is assumed to be i.i.d.

Although the binary variable $S$ in Equation (1) captures the current status of school age children, it does not measure the achievement of those who are not in school at the time of the survey. Nor does it tell us anything about the level or quality of schooling. Therefore, we consider the impact of microcredit participation on three other measures of children's educational achievement. They are (a) the number of years of school completed, (b) the "education gap," and (c) the "grade-for-age" variable. In Bangladesh, children are expected to start school at around the age of six. Therefore, we can construct a variable "education gap" to measure the achievement in terms of grade completion for a given age. The education gap can be defined as follows:

Education gap $=\max \{0$, Expected education

$$
\text { - Actual education\}, }
$$

where

Expected education

$$
= \begin{cases}0 & \text { if age } \leq 6 \\ \text { age }-6 & \text { if } 7 \leq \text { age } \leq 16\end{cases}
$$

For example, if a child successfully stayed at school as expected, the gap is 0 . If a child encountered problems such as late entry, failed grades, or dropping out, then the gap is a positive number. If a child never attended school, then the gap is the level of expected education at that age. For another measure of educational achievement, we follow Patrinos and Psacharopoulos (1997) to define a grade-for-age dependent variable as follows:

$$
\text { Grade-for-age }=100 \times(\text { Education grade } /
$$

Expected education)

where "Education grade" is the number of years a child successfully completed in school. Denoting these variables by Edu, the estimating equation is as follows:

$$
\begin{aligned}
\operatorname{Edu}_{i j k l}= & \gamma_{0 l}+\gamma_{1} X_{i j k l}+\gamma_{2} \operatorname{Credit}_{j k l} \\
& +\gamma_{3} Z_{k}+\varsigma_{i j k l} .
\end{aligned}
$$

However, estimating Equations (1)-(3) directly is problematic. There are a number of different potential sources of bias that need to be addressed in examining the effect of microcredit. First, program placement may not be random. Selection for placement could be influenced by biases in favor of high-income villages-because they may have higher participation rates - or by official bias in favor of poorer villages. We control for village-level nonrandom program placement using village fixed effects. In another specification, we use villagelevel control assuming that village-level program placement is a "selection-on-observables." The survey covers a wide range of village-level variables. Therefore, we use a set of control variables at the village level, which are included in the vector $\boldsymbol{Z}$ and are reported in Table A1. When using village-level control, we also use district-level fixed effects to remove any unobserved heterogeneity across different geographical areas. Because we have 13 MOs, each from a different district, this fixed effect also captures the heterogeneity across different MOs. Thus, we tackle the potential problem of nonrandom program placement using (a) village fixed effects and (b) geographical and MO-level fixed effects and village-level observed covariates. Our results are not affected by using either specification.

Second, households self-select into the program but not all of them are able to obtain microcredit. Generally, only eligible poor households receive microcredit, the eligibility being typically determined based on the amount of landholding. However, other factors that influence whether a household has access to microcredit could also affect outcomes for children of that household. For example, microcredit loans often require that family enterprises be established because they provide less opportunity for misuse of the loan. Poor households that operate an enterprise are also more likely to employ their children in that enterprise, and thus less likely to send them to school. It is likely that participants differ from nonparticipants in the distribution of observed characteristics, leading to a "selection-on-observables" bias. There are also problems due to "selectionon-unobservables" because of self-selection into the program (and subsequent decision on how much to borrow). Thus we need to consider the endogeneity of participation in microcredit programs at the household level. The endogeneity problem implies that selection into treatment can be affected by unobserved characteristics $\varepsilon_{i j k l}$ in Equation (1), hence a potential nonzero correlation between $\varepsilon_{i j k l}$ and Credit $j_{k}$. Consequently, 
impact estimates that use a simple probit/linear probability model (LPM) may not reflect the program's causal effect on children's school enrollment or child labor.

To account for self-selection into the program, we consider a source of exogenous variation. The MOs set the eligibility criteria for participating in the program. A household is eligible if it does not own more than a half-acre of land. The land ownership criterion is mainly used as a targeting mechanism to identify the poor. Because poverty does not exclusively depend on land ownership, however, the administrator, local loan officer, or branch manager sometimes take into account other socio-economic conditions of a household. Consequently, there are some ineligible households that receive microcredit. Although these households are a distinct minority $(70 \%$ of the treatment group in our sample is eligible), the participation in the program based on eligibility is probabilistic because the program eligibility criterion is not strictly followed. Thus our approach in estimating the treatment effect is similar to the use of fuzzy regression discontinuity design (Van der Klaauw 2002), which we implement using an instrumental variable (IV) approach.

A household does not receive microcredit if the program is not available in the village. Therefore as an instrument for the actual receipt of microcredit, we may consider the eligibility status interacted with an indicator for presence of program in a given village. Instead of using this instrument directly, however, we utilize an unexploited exogenous source of variation in the treatment intensity based on a household's exposure to the program in different villages. As shown in Figure 3, treated households in different villages appear to borrow different amounts. Intensity of treatment varies widely

\section{FIGURE 3}

Years of Microfinance Program in a Village and the Amount of Credit Borrowed by Households

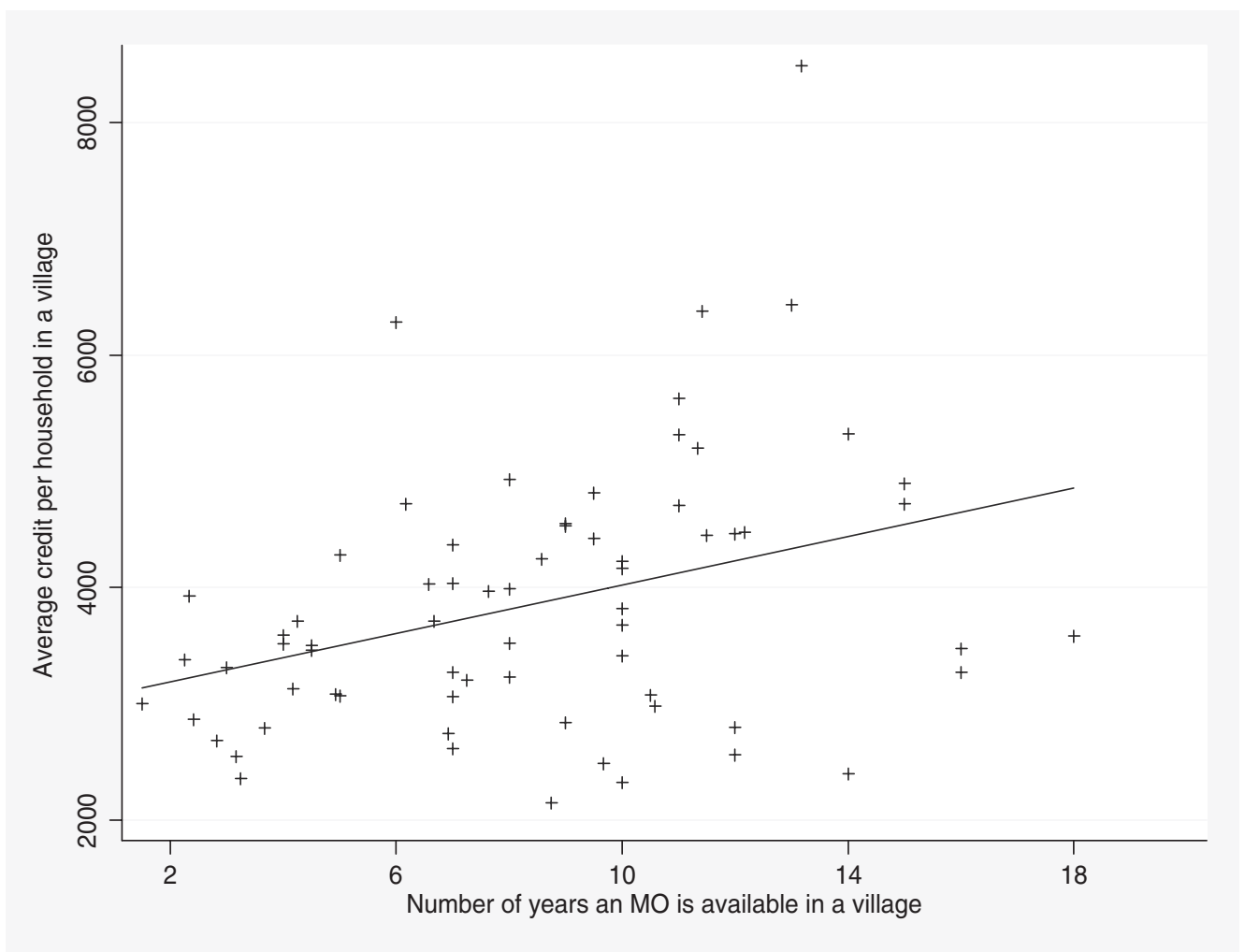

Notes: Average credit per household in a village is the amount of credit borrowed (in taka) by all households divided by the number of participating households in the program village. Number of years an MO is available in a village is the period since microcredit has been available in the program village for the first time. 
in different villages, depending on how long a microcredit program has been available in the village. In our sample, the earliest a program was made available in a village was 1980 and the latest a program became available in another village was 1997. As shown in Figure 3, the amount of credit a household borrows largely depends on how long the program has been available in the village. Thus the instrument for credit variable is the interaction among program availability, household eligibility, and the number of years microfinance has been available in a village. Ownership of land is a clear measure of wealth and eligibility is defined by land ownership. Because wealth or land could have independent effects on child labor and schooling (see, for example, Basu, Das, and Dutta 2010), we control for land ownership in our regression. ${ }^{8}$ The equation for the demand for credit then assumes the form:

$$
\begin{aligned}
\text { Credit }_{j k l}= & \delta_{0 l}+\delta_{1 j k}\left(M_{k} \times E_{j} \times N_{k}\right) \\
& +\delta_{2} X_{j k}+\xi_{j k l}
\end{aligned}
$$

where $\boldsymbol{X}$ now includes land/assets and other household-level covariates. The instrument is $I=M_{k} \times E_{j} \times N_{k}$, where $M_{k}$ is a binary variable that equals 1 if village $k$ has a microcredit program, $E_{j}$ is a binary variable that equals 1 if household $j$ is eligible (i.e., owns less than half-acre of land), and $N_{k}$ is the number of years a microcredit program has been available in village $k .^{9}$

The impact estimates are obtained using the two-stage procedure where the second-stage regression uses the value of credit from the first-stage credit demand Equation (4), which is estimated by a standard Tobit model. We report the second stage using ordinary least squares estimations of LPM. In an earlier version of this article (Islam and Choe 2009), we also reported the second-stage results using probit and the results are very similar.

A potential problem with interpreting these results when using credit as the treatment variable is that the reported amount of credit is subject to misreporting or other types of measurement error because households may

8. We also tried different land and asset-related variables including their polynomials. Our results are robust to such variations in the specification.

9. We also estimated a credit demand equation following Pitt and Khandker (1998) where interactions of eligibility and all of the household exogenous variables are used as controls. The results are similar and are available from the authors. forget or not report the amount correctly. ${ }^{10}$ This measurement error is likely to impart attenuation bias to the estimated coefficients. However, we do not think the problem of measurement error is serious in our case because we are using instrumented credit variable as the treatment variable. Nonetheless, we also use a binary treatment indicator, that is, whether or not a household is currently a member of a microcredit program, which is unlikely to be measured or reported with error. It can also serve as a robustness check of our main results. It should be noted, however, that the use of binary treatment indicator raises another issue as dummy endogenous regressors with limited dependent variables raise some econometric problems. Angrist (2001) advocates using simple IV estimators as an alternative because they require weaker assumptions and are often sufficient to answer questions of interest in empirical studies. We therefore estimate the treatment effect by using an LPM in the second stage of the IV regression.

We also control selection bias using an alternative econometric strategy. We consider corrections for endogeneity using reduced-form residuals that lead to a control function method of accounting for both selection and endogeneity. ${ }^{11}$ This is also important if the effect of credit varies across households. In that case, IV/twostage least squares (2SLS) may not estimate the average treatment effect of credit. There are, however, different approaches to estimating control functions, and not all these procedures produce consistent estimates of the treatment effect. We adopt the procedure suggested by Vella (1993), which identifies correctly the treatment effect parameter in our context. ${ }^{12}$ We first obtain generalized residuals using either Tobit

10. See, for example, Karlan and Zinman (2008) for problems with self-reported credit data.

11. The control function approach estimates the average treatment effect by controlling directly for the correlation between the error term and the outcome of equations with the treatment variable. It treats the selection bias problem as an omitted variable problem and augments the outcome equation by a term to control for this omission. The traditional example is the Heckman sample selection model that augments the outcome equation by an estimate of the Mills ratio.

12. Garen (1984) suggests a linear control function estimator to correct for endogeneity. However, Garen's approach is appropriate when the dependent variable in the first stage can take a value over a continuous range and it should be uncensored. Similarly, the two-stage conditional maximum likelihood approach of Rivers and Vuong (1988) is not applicable as the approach also requires that the credit variable be continuous (see Ravallion and Wodon 2000; Vella 1993). 
TABLE 2

First-Stage Results

\begin{tabular}{|c|c|c|c|c|}
\hline \multirow[b]{2}{*}{ Instrument } & \multicolumn{2}{|c|}{ Participation } & \multicolumn{2}{|c|}{ Credit Demand } \\
\hline & $\begin{array}{l}\text { Probit } \\
\text { (1) }\end{array}$ & $\begin{array}{c}\text { Probit } \\
\text { (2) }\end{array}$ & $\begin{array}{c}\text { Tobit } \\
\text { (3) }\end{array}$ & $\begin{array}{c}\text { Tobit } \\
\text { (4) }\end{array}$ \\
\hline$M \times E$ & $0.5059(11.59)^{* *}$ & - & $1,017.2(7.27)^{* *}$ & - \\
\hline$M \times E \times N$ & - & $0.0437(10.07)^{* * *}$ & - & $103.22(7.61)^{* * *}$ \\
\hline
\end{tabular}

Notes: Regressions include controls and fixed effects. Absolute value of $t$-statistics is presented in parentheses.

Coefficients with $* *$ are significant at the $1 \%$ level.

(for credit as the treatment variable) or probit (for binary treatment indicator) for the reducedform first-stage equation, and then use the estimated residuals as an additional regressor in the second stage. ${ }^{13}$

\section{A. First Stage and the Instrument Validity}

Before we move on to estimation results, we offer further discussions on our identification strategy and the validity of our instrument. Identification requires that land ownership be exogenous conditional on program participation. The validity of the land-based eligibility criterion as an instrument for microcredit participation in Bangladesh is also defended at length by Pitt and Khandker (1998). Because credit is extended mainly for self-employment activities, households having more land are exogenously ruled out. However, some participating households own more than half an acre of land. These households are either currently not actively engaged in agriculture or their land is not fertile for cultivation, or they participate in microcredit programs because of mistargeting as perfect monitoring is not possible. The eligibility rule is set to simply identify the poverty status of the household. Because land price and quality also vary between different regions, a household having more than half an acre of land may be considered to be poor in some regions, as subjectively judged by the loan officer or branch manager. On the other hand, richer households typically obtain credit from formal markets, or through other means. Also there are social norms that bar them from becoming members of an MO. Moreover, rich people in rural areas hesitate to become members of MFI, because they consider MFI as an organization for the poor. Thus the use of eligibility criterion

13. This model is identified even without the exclusion restrictions because of the nonlinearity of the residuals. as an instrument for treatment in microfinance is well justified. Finally, we stress that our identification strategy does not depend exclusively on the eligibility rule because we also exploit the variation in credit demand among households in different villages based on the availability of program in different villages. Thus, it is the interactions of these three variables $(M, E$, and $N$ ) that need to be exogenous.

In the following, we discuss the validity of our instrument. We test whether the IVs are correlated with the endogenous regressor and orthogonal to the error process. By definition, the instrument should be correlated with the endogenous regressor ("credit" variable), and it should not be correlated with outcomes of interest (child labor or schooling) through any channel other than via its influence on endogenous regressor. The instrument should also be orthogonal to any other omitted characteristics reflected in the error term in Equation (1). The first-stage regression results are reported in Table 2 using both probit (for participation) ${ }^{14}$ and Tobit (for credit demand) models based on Equation (4). The Tobit results show that both instruments $M \times E$ and $M \times E \times N$ are highly statistically significant with $t$-statistics above seven in both cases. The coefficient estimate is positive and also economically significant, implying that our instrument is significantly related to the demand for credit. We estimate the participation decision equation by regressing a binary indicator for participation on an

14. For the first-stage regression, we use the nonlinear probit model instead of the LPM. We prefer probit because in the case of IV estimation, the untestable assumption is the exclusion restriction. However, this assumption is not strictly required when a nonlinear binary response regression is used instead of the LPM (see Ravallion 2008). We have also tried linear models in both stages of the IV estimation but our conclusions remain intact. The first-stage results using the LPM for binary participation measure show that $t$-statistics are always greater than 10 . 
TABLE 3

Reduced-Form Results -Effects of Eligibility on Schooling/Work

\begin{tabular}{lcc}
\hline & $\begin{array}{c}\text { Child in School } \\
(\mathbf{1})\end{array}$ & $\begin{array}{c}\text { Child in Work } \\
\text { (2) }\end{array}$ \\
\hline Eligibility & $-0.036(0.042)$ & $-0.019(0.026)$ \\
Observations & 4,277 & 4,277 \\
$R^{2}$ & 0.245 & 0.246 \\
\hline
\end{tabular}

Notes: Regressions also include instrumented credit variable, child and household characteristics, and village fixed effects. Standard errors presented in parentheses are corrected for clustering at the village level.

indicator of interaction between eligibility and program village dummies (plus all controls). The results are stronger with $t$-statistics above 10 .

Because we have a single instrument for the credit variable, we cannot test the exogeneity of the instrument as in an over-identified model. The remaining concern is whether the instrument satisfies the exclusion restriction, that is, whether eligibility affects child labor or school enrollment only through participation in the credit program or the amount of credit borrowed conditional on the amount of land, demographic, and other socio-economic characteristics. Although the exclusion restriction is not directly testable, we address this concern in a number of ways. First, we estimate a reducedform regression to examine the effect of loan eligibility on school enrollment/child labor. The results, reported in Table 3, indicate that there is no effect of eligibility or program placement on school enrollment and child labor. We also estimate an equation in which credit is instrumented but instrument eligibility enters the second-stage regression directly (and naturally in the firststage regression). By definition of IV, the instrument should be uncorrelated with the outcomes of interest through any channels other than their effects via the endogenous regressors. Therefore, once the credit is instrumented, eligibility itself should have no effect on schooling or child labor when both instrumented credit and eligibility are entered as controls for child labor/school enrollment equation. The results in Table 3 do not indicate any significant effect of eligibility in any of the specifications.

\section{EMPIRICAL FINDINGS}

This section reports our empirical findings where the estimated value of credit from the first-stage regression is used as the regressor in the second-stage estimation. We estimate the impact of credit extended to women and men separately. ${ }^{15}$ This is to see how the gender of participants in the microcredit program affects schooling and work decision for their children. We estimate the results separately for boys and girls by credit given to both women and men.

Table 4 reports the estimates of the secondstage regression. All coefficients are estimated using LPM. ${ }^{16}$ The results in columns (1) and (2) indicate that participation in microcredit programs significantly increases the probability of child labor for girls. For boys, there is some indication that microcredit reduces the probability of child labor especially when credit is obtained by women. Overall, the impact of microcredit on child labor is positive and significant. The qualitative results are independent of whether credit is obtained by men or women. For example, microcredit increases the probability of child labor for girls by $13.7 \%$ using both village fixed effects and village controls. The probability increases to $14 \%-16 \%$ when women are borrowers. For boys, women's credit has an insignificant but detrimental effect. Table 4 also shows that girls are affected more adversely, and boys more favorably, when credit is obtained by men than by women, although these estimates are not statistically significant. A Hausman-like test does not support the difference in treatment effect between men and women borrowers. The overall finding is that participation in microcredit programs increases the likelihood of child labor for girls while the impact on boys is less clear.

Columns (3) and (4) in Table 4 report the effect of microcredit on school enrollment. The results overwhelmingly indicate that access to microcredit negatively affects children's school enrollment. This is true across all regression models and regardless of whether we use village fixed effects or village controls. The negative effect is especially pronounced for girls although, for boys, it is statistically insignificant in many cases. For example, microcredit decreases the probability of school enrollment

15. Although credit is given to both women and men in different villages, credit groups are never mixed by gender. Households do not have choice over which gender is to participate as MOs select one or the other gender, but not both.

16. The results do not change when using probit in the second stage, which are reported in an earlier version of this article (Islam and Choe 2009). 
TABLE 4

Impact Estimates on Child Work and Schooling

\begin{tabular}{|c|c|c|c|c|}
\hline & \multicolumn{2}{|c|}{ Child in Work } & \multicolumn{2}{|c|}{ Child in School } \\
\hline & $\begin{array}{l}\text { Village Control } \\
\text { (1) }\end{array}$ & $\begin{array}{c}\text { Village Fixed Effects } \\
\text { (2) }\end{array}$ & $\begin{array}{l}\text { Village Control } \\
\text { (3) }\end{array}$ & $\begin{array}{c}\text { Village Fixed Effects } \\
\text { (4) }\end{array}$ \\
\hline \multicolumn{5}{|c|}{ Women and men's credit } \\
\hline All & $0.0801(0.0441)^{\dagger}$ & $0.119(0.041)^{* *}$ & $-0.1588(0.0688)^{* *}$ & $-0.219(0.065)^{* *}$ \\
\hline Boys & $0.0034(0.0583)$ & $0.075(0.070)$ & $-0.0756(0.0825)$ & $-0.159(0.079)^{*}$ \\
\hline Girls & $0.1367(0.0594)^{* * *}$ & $0.137(0.054)^{*}$ & $-0.2261(0.0905)^{* *}$ & $-0.246(0.093)^{* *}$ \\
\hline \multicolumn{5}{|c|}{ Women's credit } \\
\hline All & $0.087(0.0456)^{\dagger}$ & $0.134(0.066)^{*}$ & $-0.1717(0.0694)^{* *}$ & $-0.213(0.093)^{*}$ \\
\hline Boys & $0.0129(0.0590)$ & $0.067(0.109)$ & $-0.0965(0.0846)$ & $-0.102(0.123)$ \\
\hline Girls & $0.1426(0.0610)^{* * *}$ & $0.159(0.089)^{\dagger}$ & $-0.2296(0.0921)^{* *}$ & $-0.287(0.123)^{*}$ \\
\hline \multicolumn{5}{|c|}{ Men's credit } \\
\hline All & $0.0774(0.0746)$ & $0.133(0.040)^{* *}$ & $-0.1423(0.1108)$ & $-0.246(0.067)^{* *}$ \\
\hline Boys & $-0.0239(0.0912)$ & $0.089(0.065)$ & $-0.0194(0.1372)$ & $-0.195(0.079)^{*}$ \\
\hline Girls & $0.1507(0.1094)$ & $0.147(0.055)^{* *}$ & $-0.2635(0.1496)^{\dagger}$ & $-0.256(0.099)^{*}$ \\
\hline
\end{tabular}

Notes: All the results are the marginal effects of instrumented credit variable using IV regressions. The regressions also include child and household characteristics. Standard errors presented in the parentheses are corrected for clustering at the village level using the formulas by Liang and Zeger (1986). The coefficients and the standard errors are multiplied by the average credit borrowed by the respective group of households.

Coefficients with ${ }^{\dagger}$ are significant at the $10 \%$ level, those with $* *$ at the $5 \%$ level, and those with $*$ at the $1 \%$ level.

TABLE 5

Impact Estimates Based on Binary Participation Measure

\begin{tabular}{|c|c|c|c|c|}
\hline & \multicolumn{2}{|c|}{ Child in School } & \multicolumn{2}{|c|}{ Child in Work } \\
\hline & Village Control & Village Fixed Effect & Village Control & Village Fixed Effect \\
\hline \multicolumn{5}{|c|}{ Women's credit } \\
\hline Boys & $-0.1690(0.1374)$ & $-0.223(0.179)$ & $0.0193(0.0956)$ & $0.132(0.146)$ \\
\hline Girls & $-0.4782(0.1359)^{*}$ & $-0.471(0.176)^{* *}$ & $0.2569(0.0946)^{*}$ & $0.281(0.119)^{*}$ \\
\hline \multicolumn{5}{|c|}{ Men's credit } \\
\hline Boys & $-0.1190(0.1744)$ & $-0.248(0.128)^{\dagger}$ & $0.0097(0.1175)$ & $0.087(0.091)$ \\
\hline Girls & $-0.5828(0.1782)^{*}$ & $-0.408(0.134)^{* *}$ & $0.3019(0.1357)^{* *}$ & $0.194(0.084)^{*}$ \\
\hline
\end{tabular}

Notes: All the results are the marginal effects of instrumented binary treatment indicator variable using IV regressions. The regressions also include child- and household-specific covariates. Standard errors presented in the parentheses are corrected for clustering at the village level using the formulas by Liang and Zeger (1986).

Coefficients with ${ }^{\dagger}$ are significant at the $10 \%$ level, those with $* *$ at the $5 \%$ level, and those with $*$ at the $1 \%$ level.

for girls by $22.6 \%$ using village controls and $24.6 \%$ using village fixed effects. The negative effect on boys' school enrollment is larger when women are borrowers although it is statistically insignificant in Model (3). One might surmise that this could be an indication of gender preference by parents. However, Hausman-type tests do not reject the equality of the coefficients between the sexes of the borrower. Overall, the (negative) effects of credit on schooling are larger than the effects on child labor, suggesting that households might be under-reporting child labor or some children are away from school and doing nothing.
Table 5 shows the treatment-on-treated effect using a binary participation indicator as the treatment variable. The estimated effect using 2SLS is identical to the indirect least squares estimate obtained from taking the ratio of the reduced-form coefficients, because we are estimating a just identified equation. The results are qualitatively similar to those in Table 4. Girls' education continues to be affected adversely by parental participation in microcredit programs whether credit is obtained by men or women. Using village fixed effects, for example, we find that women's microcredit borrowing increases the probability of girls' child labor 
TABLE 6

Impact Estimates on Children's School Achievement

\begin{tabular}{|c|c|c|c|c|c|c|}
\hline & \multicolumn{3}{|c|}{ Boys } & \multicolumn{3}{|c|}{ Girls } \\
\hline & $\begin{array}{c}\text { Grade } \\
\text { Completion }\end{array}$ & $\begin{array}{l}\text { Education } \\
\text { Gap }\end{array}$ & Grade-For-Age & $\begin{array}{c}\text { Grade } \\
\text { Completion }\end{array}$ & $\begin{array}{l}\text { Education } \\
\text { Gap }\end{array}$ & Grade-For-Age \\
\hline \multicolumn{7}{|c|}{ Female borrower } \\
\hline $\begin{array}{l}\text { Treatment } \\
\text { effect }\end{array}$ & $-0.196(0.617)$ & $-0.092(0.611)$ & $-21.64(12.912)^{\dagger}$ & $-2.95(0.738)^{*}$ & $2.752(0.696)^{*}$ & $-48.393(16.089) *$ \\
\hline $\begin{array}{l}\text { Control } \\
\text { function }\end{array}$ & $0.158(0.624)$ & $0.143(0.617)$ & $22.29(13.283)^{\dagger}$ & $2.963(0.745)^{*}$ & $-2.755(0.705)^{*}$ & $49.405(16.256)^{*}$ \\
\hline \multicolumn{7}{|l|}{ Male borrower } \\
\hline $\begin{array}{l}\text { Treatment } \\
\text { effect }\end{array}$ & $-0.423(0.846)$ & $0.043(0.817)$ & -23.727 (17.603) & $-3.77(0.961)^{*}$ & $3.39(0.923)^{*}$ & $-72.49(21.299)^{*}$ \\
\hline $\begin{array}{l}\text { Control } \\
\text { function }\end{array}$ & $0.327(0.787)$ & $0.047(0.765)$ & $25.084(16.855)$ & $3.537(0.958)^{*}$ & $-3.199(0.921)^{*}$ & $69.1(21.373)^{*}$ \\
\hline
\end{tabular}

Notes: All the results are estimated using the control function method. The regressions include child- and householdspecific covariates, village-level covariates, and district fixed effects. The coefficients and the standard errors of treatment effects are multiplied by the average credit borrowed by male and female borrowers. Standard errors presented in the parentheses are corrected for clustering at the village level using the formulas by Liang and Zeger (1986).

Coefficients with ${ }^{\dagger}$ are significant at the $10 \%$ level and those with * at the $1 \%$ level.

by $28 \%$ and decreases the probability of their school enrollment by $47 \%$. The magnitude of the impact estimates is similar in case the borrower is a man. The corresponding coefficient estimates for child labor for boys are not statistically significant and have mixed signs. Overall, binary participation measures generate considerably larger coefficient estimates for girls. However, these results are only indicative as they do not take into account the variation of treatment intensity, and assume the treatment effect to be the same for all children in the treatment group.

The estimates using educational achievement measures are reported in Table $6 .{ }^{17}$ The negative coefficients for grade completion and grade-forage, and the positive coefficient for education gap all imply that participation in microcredit programs adversely affects children's educational achievement. Once more, girls are more adversely affected than boys: coefficient estimates for girls are larger than for boys and statistically significant at the $1 \%$ level. Women's participation in microcredit reduces girls' education by about 3 years of schooling, whereas the corresponding decrease for boys' education is about 0.2 years of schooling. Men's participation has a larger negative impact on girls'

17. The results reported in this section use the control function approach discussed in the previous section. The results using the IV/2SLS approach are similar to those reported here and are available upon request from the authors. grade completion - a reduction of 3.8 years in schooling compared with the girls from the control group. The effects on boys' school achievement are not statistically significant in general. The results from all three measures of educational achievement are similar, which are not particularly surprising because the three measures are likely to be highly correlated.

In further tests reported in an earlier version of this article (Islam and Choe 2009), we also find that younger children are more adversely affected than their older siblings and the children of poorer and less educated households are affected more adversely. These results indicate that microcredit to the poorest of the poor households neither alleviates the problem of child labor nor improves children's schooling as poorer households among the clients are more adversely affected than their less poor counterparts.

A possible explanation for the adverse effect of microcredit on children's schooling is that microcredit increases demand for labor in household enterprises set up with microcredit, which may cause children's time to be diverted away from school into household enterprises. We examine this issue below. We classify a child's current status into five different categories based on the detailed occupational information collected during the survey. They are (a) selfemployment activity (in household enterprise), (b) agricultural activity, (c) day labor, (d) service-related activity, and (e) student (enrolled 
TABLE 7

Multinomial Logit Model for Children's Work/School Status

\begin{tabular}{lcl}
\hline Child Status & Coefficient & Marginal Effect \\
\hline Self-employment activity & $2.03(0.71)^{*}$ & $0.266(0.095)^{*}$ \\
Agriculture & $-6.48(1.73)^{*}$ & $0.000(0.0000)^{*}$ \\
Day laborer & $1.33(1.07)$ & $0.0000(0.001)$ \\
Service-related activity & $2.42(4.50)$ & $0.0000(0.0000)$ \\
Enrolled in school & - & $-0.266(0.096)^{*}$ \\
\hline
\end{tabular}

Notes: The regressions include child- and householdspecific covariates, village-level covariates, and district fixed effects. Standard errors presented in the parentheses are corrected for clustering at the village level using the formulas by Liang and Zeger (1986).

Coefficients with $*$ are significant at the $1 \%$ level.

in school). ${ }^{18}$ We run a multinomial logit model where the parameter of interest is the coefficient corresponding to the instrumented credit variable obtained from Equation (4). Table 7 reports the odds ratios and corresponding marginal effects of the treatment variable. The results show that, for children from treated households, the odds of being in self-employment activities instead of being in school are more than doubled. The corresponding marginal effect indicates that children from treated households are $26.6 \%$ more likely to work in self-employment activities than those from nontreated households. The odds ratio is higher and negative for agricultural activity. However, the corresponding marginal effect is economically insignificant. The rest of the coefficient estimates is not statistically significant. Finally, the marginal effect for the student status implies that children from treated households have a $26.6 \%$ lower chance of being enrolled in school than those from nontreated households. Overall, these results support the explanation that children from treated households are more likely to work in household enterprises set up with microcredit.

\section{SUMMARY AND CONCLUSION}

This article has studied the impact of access to microcredit on children's education and child labor using a new and large data set consisting of treated and nontreated microcredit households from Bangladesh. The results overwhelmingly indicate that household participation in

18. Only a very few households (less than $1 \%$ ) reported that their children are only doing household work. Therefore, we do not include them in our regression. microcredit programs has adverse effects on children's schooling, which are especially pronounced for girls. It appears that children taken out from school are more likely to work in household enterprises that are set up with microcredit than in other types of work. Overall, our results suggest that care needs to be taken in assessing the effectiveness of microcredit programs. Although microcredit programs can alleviate poverty and contribute to rural economy in the short term, they can also result in unintended consequences of adversely affecting children's schooling, which could exacerbate poverty in the longer term. An additional concern relates to the gender-asymmetric impact of access to microcredit. Government policies aimed at rectifying gender imbalance in education may turn out to be less effective in the presence of many active microcredit programs.

A number of policies can be adopted to mitigate the adverse effect on child labor and schooling so that microcredit can benefit both current and future generations (Wydick 1999). At the level of MOs, the gestation period between actual loan disbursement and the start of repayment can be extended. This allows many households to invest in suitable investment projects where they may find a greater balance between employing children at household enterprises and sending them to school. Reduced interest rates and longer repayment periods can also help households to become less myopic. In addition, increases in the size of credit allowing employment of external labor can take the burden off from households to resort to child labor. The latter suggests that MOs may eventually need to look further and consider financing rural enterprises at the village level rather than at the household level. These measures that are directed at MOs alone are by no means sufficient in reducing child labor and improving child schooling. They need to be complemented by policies that directly target children's education, of which the essence is to increase the return on education perceived by parents. In summary, microcredit programs need to be complemented by other policies to tackle the multiple goals of poverty reduction, human capital formation, and social development. It is, however, to be noted that we estimate here only the contemporaneous effect of microcredit. It is entirely possible (and plausible) that the long-run results could be opposite. That is, the higher income opportunities provided by microcredit over time may lead to an income effect toward less child 
labor and more education that may outweigh the substitution effect. Therefore, our results should be interpreted with caution, and perhaps a panel data set over a longer term participation in microcredit can address the issue concerning short- versus long-run effects.

\section{APPENDIX}

TABLE A1

Descriptive Statistics of Village-Level Controls

\begin{tabular}{|c|c|c|c|}
\hline Variable & $\begin{array}{c}\text { Control } \\
\text { Village (I) }\end{array}$ & $\begin{array}{c}\text { Program } \\
\text { Village (II) }\end{array}$ & $\begin{array}{c}\text { Difference } \\
\text { III = (II-I) }\end{array}$ \\
\hline \multicolumn{4}{|l|}{ Education facilities } \\
\hline Primary school & 90.91 & 86.25 & -4.66 \\
\hline Secondary school & 27.27 & 31.25 & 3.98 \\
\hline Maktab/Madrasa (religious school) & 81.82 & 90.00 & 8.18 \\
\hline \multicolumn{4}{|l|}{ Health facilities } \\
\hline Union health center & 10 & 17.5 & 7.5 \\
\hline Allopathic doctor & 50 & 42.5 & -7.5 \\
\hline Homeopathic doctor & 40 & 38.75 & -1.25 \\
\hline \multicolumn{4}{|l|}{ Transport, communication, and infrastructure } \\
\hline Electricity connection & 17 & 26 & 9.0 \\
\hline Presence of pucca road & 10.6 & 34.8 & 24.2 \\
\hline Distance to nearest thana $(\mathrm{km})$ & 11.91 & 7.14 & -4.77 \\
\hline Presence of grocery market & 18.2 & 22.5 & 4.3 \\
\hline Presence or absence of frequent haat (big market) & 27.3 & 32.5 & 5.2 \\
\hline Presence of bus stand & 9.1 & 15 & 5.9 \\
\hline Presence of post office & 18.2 & 20 & 1.8 \\
\hline Presence of telephone office & 9.1 & 6.3 & -2.8 \\
\hline Presence of Union Parishad (local Government) office & 18.2 & 13.8 & -4.4 \\
\hline \multicolumn{4}{|l|}{ Irrigation equipment } \\
\hline Number of low lift pumps & 0.27 & 0.44 & 0.16 \\
\hline Number of shallow tube wells & 11.82 & 12.13 & 0.31 \\
\hline Number of hand tube wells for drinking water & 68 & 78.04 & 10.04 \\
\hline \multicolumn{4}{|l|}{ Credit-related variables } \\
\hline Percentage of crop received by land owner in sharecropping & 49.55 & 47.53 & -2.02 \\
\hline Number of people who provide advances against crops & 2.73 & 3.85 & 1.12 \\
\hline Number of small credit/savings groups & 0.91 & 0.76 & -0.15 \\
\hline
\end{tabular}

Notes: The first two columns show the mean of each variable for the control and treatment villages. The third column is the difference between the two, with differences that are statistically significant at less than 5\% marked bold.

\section{REFERENCES}

Angrist, J. "Estimation of Limited Dependent Variable Models with Dummy Endogenous Regressors: Simple Strategies for Empirical Practice." Journal of Business \& Economic Statistics, 19(1), 2001, 2-16.

Baland, J.-M., and J. A. Robinson. "Is Child Labor Inefficient?" Journal of Political Economy, 108(4), 2000, 663-79.

Banerjee, A., E. Duflo, R. Glennerster, and C. Kinnan. "The Miracle of Microfinance? Evidence from a Randomized Evaluation." Working Paper, Department of Economics, MIT, 2009.

Basu, K., S. Das, and B. Dutta. "Child Labor and Household Wealth: Theory and Empirical Evidence of an InvertedU." Journal of Development Economics, 91(1), 2010, $8-14$.

Behrman, J., and J. Knowles. "Household Income and Child Schooling in Vietnam." World Bank Economic Review, 13(2), 1999, 211-56.
Dehejia, R., and R. Gatti. "Child Labour: The Role of Income Variability and Access to Credit across Countries." Economic Development and Cultural Change, 53(4), 2005, 913-32.

Doepke, M., and F. Zilibotti. "The Macroeconomics of Child Labor Regulation." American Economic Review, 95(5), 2005, 1492-524.

Edmonds, E. "Child Labour and Schooling Responses to Anticipated Income in South Africa." Journal of Development Economics, 81(2), 2006, 386-414.

- "Child Labour," in Handbook of Development Economics, Vol. 4, edited by T. P. Schultz and J. Strauss. Amsterdam, The Netherlands: North-Holland Elsevier Science, 2007, 3607-709.

Garen, J. "The Returns to Schooling: A Selectivity Bias Approach with a Continuous Choice Variable." Econometrica, 52(5), 1984, 1199-218.

Hazarika, G., and S. Sarangi. "Household Access to Microcredit and Child Labour in Rural Malawi." World Development, 36(5), 2008, 843-59. 
Islam, A., and C. Choe "Child Labour and Schooling Responses to Access to Microcredit in Rural Bangladesh.” MPRA Paper 16842, University Library of Munich, Germany, 2009.

Jacoby, H. "Borrowing Constraints and Progress through School: Evidence from Peru." Review of Economics and Statistics, 76(1), 1994, 151-60.

Jacoby, H., and E. Skoufias. "Risk, Financial Markets, and Human Capital in a Developing Country." Review of Economic Studies, 64(3), 1997, 311-35.

Karlan, D., and J. Zinman. "Lying About Borrowing." Journal of the European Economic Association, 6(2-3), 2008, 510-21.

. "Expanding Microenterprise Credit Access: Using Randomized Supply Decisions to Estimate the Impacts in Manila." Review of Financial Studies, 23(1), 2009, 433-64.

Liang, K., and S. Zeger. "Longitudinal Data Analysis Using Generalized Linear Models." Biometrika, 73(1), 1986, 13-22.

Maldonado, J., and C. Gonzalez-Vega. "Impact of Microfinance on Schooling: Evidence from Poor Rural Households in Bolivia." World Development, 36(11), 2008, $2440-55$.

Patrinos, H., and G. Psacharopoulos. "Family Size, Schooling and Child Labour in Peru-An Empirical Analysis." Journal of Population Economics, 10(4), 1997, 387-405.

Pitt, M., and S. Khandker. "The Impact of Group-Based Credit Programs on Poor Households in Bangladesh: Does the Gender of Participation Matter?" Journal of Political Economy, 106(5), 1998, 958-96.

Ranjan, P. "An Economic Analysis of Child Labour." Economics Letters, 64(1), 1999, 99-105.
"Credit Constraints and the Phenomenon of Child Labour." Journal of Development Economics, 64(1), 2001, 81-102.

Ravallion, M. "Evaluating Anti-Poverty Programs," in Handbook of Development Economics, Vol. 4, edited by P. Schultz and J. Strauss. Amsterdam, The Netherlands: North-Holland, 2008, 3787-846.

Ravallion, M., and Q. Wodon. "Does Child Labour Displace Schooling? Evidence on Behavioural Responses to an Enrolment Subsidy.” Economic Journal, 110(462), 2000, C158-75.

Rivers, D., and Q. Vuong. "Limited Information Estimators and Exogeneity Tests for Simultaneous Probit Models." Journal of Econometrics, 39(3), 1988, 347-66.

Van der Klaauw, W. "Estimating the Effect of Financial Aid Offers on College Enrolment: A RegressionDiscontinuity Approach." International Economic Review, 43(4), 2002, 1249-87.

Vella, F. "A Simple Estimator for Simultaneous Models with Censored Endogenous Regressors." International Economic Review, 34(2), 1993, 441-57.

World Bank. Microfinance in South Asia: Towards a Financial Inclusion for the Poor. Washington, DC: The World Bank, 2006.

Wydick, B. "The Effect of Microenterprise Lending on Child Schooling in Guatemala." Economic Development and Cultural Change, 47(4), 1999, 853-69.

Zohir, S., S. Mahmud, B. Sen, and M. Asaduzzaman. Monitoring and Evaluation of Microfinance Institutions. Dhaka: Bangladesh Institute of Development Studies, 2001. Accessed April 26, 2011. http://www.pksfbd.org. 